\title{
Poor prognostic value of proliferating cell nuclear antigen labelling index in breast carcinoma
}

\author{
M Thomas, M Noguchi, H Kitagawa, K Kinoshita, I Miyazaki
}

\begin{abstract}
Aim-To investigate the association between proliferating cell nuclear antigen immunostaining and various clinicopathological variables, and its prognostic value in breast carcinoma.

Methods-A monoclonal antibody PC10 was applied to formalin fixed, paraffin wax embedded tissue in 144 cases of primary breast cancer. PCNA immunostaining was scored by counting 1000 cells; the percentage of positive stained cells was recorded as the PCNA labelling index (PCNA-LI).

Results-The PCNA-LI varied from $0-77 \%$ with a mean of $18 \%$. When tumours were separated on the basis of the mean value, 93 had a low PCNA-LI of less or equal than $18 \%$ and 47 a high PCNA-LI of more than $18 \%$. There was no significant correlation between PCNA-LI and all prognostic factors included in this study. Moreover, PCNAII failed to show any prognostic value for overall and disease free survival.

Conclusion-PCNA immunostaining is not correlated with clinicopathological variables and patient survival in breast cancer.
\end{abstract}

(F Clin Pathol 1993;46:525-528)

The clinical outcome of patients with breast cancer is highly variable because it not only depends on the extent of disease but also on its behaviour. Tumour cell proliferation is an important biological variable which can be regarded as an additional prognostic factor. ${ }^{1}$ To date, however, methods used to assess this variable have had limited success. The methods which require labelling with ${ }^{3} \mathrm{H}$ thymidine or its non-radioactive analogue bromodeoxyuridine, ${ }^{2}$ or disruption of cellular and tissue architecture for DNA flow cytometry, ${ }^{3}$ are complex procedures that are time consuming and can not really be applied to routine clinical samples. More recently, a monoclonal antibody $\mathrm{Ki} 67$ was produced. It reacts with a nuclear antigen present throughout the cell cycle of proliferating cells. ${ }^{4} \mathrm{~A}$ major drawback to its use, however, has been the need for fresh or snap frozen material. ${ }^{5}$

Autoantibodies from patients with systemic lupus erythematosus have been described as recognising a nuclear antigen called proliferating cell nuclear antigen (PCNA), present in proliferating cells. ${ }^{67}$ This antigen is a 36 kilodalton nuclear protein which is directly involved in DNA synthesis and replication. ${ }^{89}$ During the cell cycle, PCNA expression increases through G1 phase, shows a maximum at the early $S$ phase, declines through G2 phase, and reaches low levels in M phase and interphase. ${ }^{1011}$ Several groups have reported that antibodies against PCNA are useful probes for the detection of proliferating cells in normal and neoplastic tissues ${ }^{12-17}$ and that they have prognostic value in certain tumour populations. ${ }^{1819}$ There are also a few studies in which PCNA failed to show any prognostic value. ${ }^{20}$

Using the new monoclonal antibody PC10, ${ }^{21}$ which can be applied to routinely fixed, paraffin wax embedded tissue, we investigated the association between PCNA index and several clinical and biological variables, and the prognostic value of the PCNA index on the survival of patients with breast carcinoma.

\section{Methods}

One hundred and forty four paraffin wax blocks of tumour samples were available from patients with resectable breast cancer treated at the Second Department of Surgery, Kanazawa University Hospital, between 1978 and 1989. We selected patients with histologically confirmed breast carcinomas in whom a variety of mastectomies with axillary lymph node (AX) dissection had been performed. All resected material was examined histologically. Postoperatively, all patients were undergoing various adjuvant hormone treatments. They were followed up until their death, or to March 1992.

The patients were classified according to the following clinicopathological variables: age (14 aged $\leq 35$ years, 69 aged $36-50$ years, 61 aged $\geq 51$ years); menopausal status (78 premenopausal, 66 postmenopausal; clinical stage (five with tumour in situ, 28 in stage 1,76 in stage 2,35 in stage 3 ); tumour size $(\leq 2.0 \mathrm{~cm}$ in $58,2 \cdot 1-5.0 \mathrm{~cm}$ in $70, \geq 5 \cdot 1$ $\mathrm{cm}$ in 16); histological type (non-invasive carcinoma in five, invasive ductal carcinoma in 130 , special type of invasive carcinoma in nine) according to the histological classification of breast cancer of the Japan Breast Cancer Society ${ }^{22}$ and the modified histological typing of the World Health Organisation $^{23}$; degree of histological AX metastases ( 0 in 85 , one to three in 33, $>$ three in 26$)$; and PCNA index ( $\leq 18 \%$ in $93,>18 \%$ in 51 ). 
PCNA IMMUNOSTAINING

Formalin fixed, paraffin wax embedded tissue sections $(5 \mu \mathrm{m})$ were dewaxed in xylene and subsequently rehydrated in graded ethanol solutions. Endogenous peroxidase activity was blocked by immersing the sections in $1 \%$ hydrogen peroxide in methanol for $15 \mathrm{~min}$ utes. After washing in distilled water for five minutes and in phosphate buffered saline (PBS, pH 7.4) for 20 minutes, the sections were preincubated with $10 \%$ normal goat serum (Dako, Copenhagen, Denmark) in PBS with $0 \cdot 1 \%$ bovine serum albumin (BSA) for 20 minutes at room temperature. The sections were then incubated overnight at $4^{\circ} \mathrm{C}$ with the PC10-murine IgG2a antiPCNA monoclonal antibody (Novocastra Laboratories, Newcastle upon Tyne, England) at one in 50 dilution in phosphate buffered saline-bovine serum albumin (PBSBSA). After rinsing in PBS, the sections were incubated with a biotinylated antimouse immunoglobulin (Dako) for 90 minutes at room temperature, followed by a rinse in PBS. The site of the antibody binding was visualised with streptavidin-biotin-peroxidase complex (Dako) for 60 minutes. Diaminobenzidine-hydrogen peroxide was used as a chromogen and a light haematoxylin counterstain was used. The sections were then rinsed in tap water for five minutes, dehydrated in ethanol, cleared in xylene and mounted under coverslips in malinol medium (Muto Pure Chemicals, Tokyo, Japan). Negative controls were done by omitting the primary antibody. PCNA immunostaining was scored by counting 1000 cells in 10 to 20 fields per tumour depending on cellularity. Every stained nucleus was considered positive regardless of its intensity. In cases where staining varied in the tumour, the fields examined included those with the highest and those with the lowest percentage of stained cells. The percentage of positive stained cells was recorded as the PCNA labelling index (PCNA-LI).

\section{STATISTICAL ANALYSIS}

The PCNA-LI and other clinicopathological variables were analysed using the $\chi^{2}$ test. Disease free and overall survivals were calculated as the interval from the date of the operation to the recurrence or the death from causes related to breast cancer, respectively. For univariate analysis, the overall and disease free survivals were studied using the Kaplan-Meier method, and the log-rank test was used to analyse differences for signifcance. For multivariate analysis, Cox's life table regression model (proportional hazards general linear model) was used to examine several variables simultaneously to test for their independent prognostic values. Differences were considered significant when the $\mathrm{p}$ value was less than 0.05 .

\section{Results}

ASSOCIATION BETWEEN PCNA-LI AND CLINICAL AND HISTOLOGICAL VARIABLES

PCNA staining was confined to nuclei (figure) and showed diffuse, granular, or a mixture of both types of staining. Some cells stained more strongly than others, but all identifiable staining was regarded as positive. PCNA positivity showed pronounced variation among tumors and the index varied from $0-77 \%$ with a mean of $18 \%$. To evaluate the association between PCNA-LI and the clinicopathological factors, tumours were separated on the basis of the mean value. Ninety three tumors had a low PCNA-LI of less or equal than $18 \%$ and 47 a high PCNA index
PC10 immunostaining of breast cancer showing many positive nuclei.

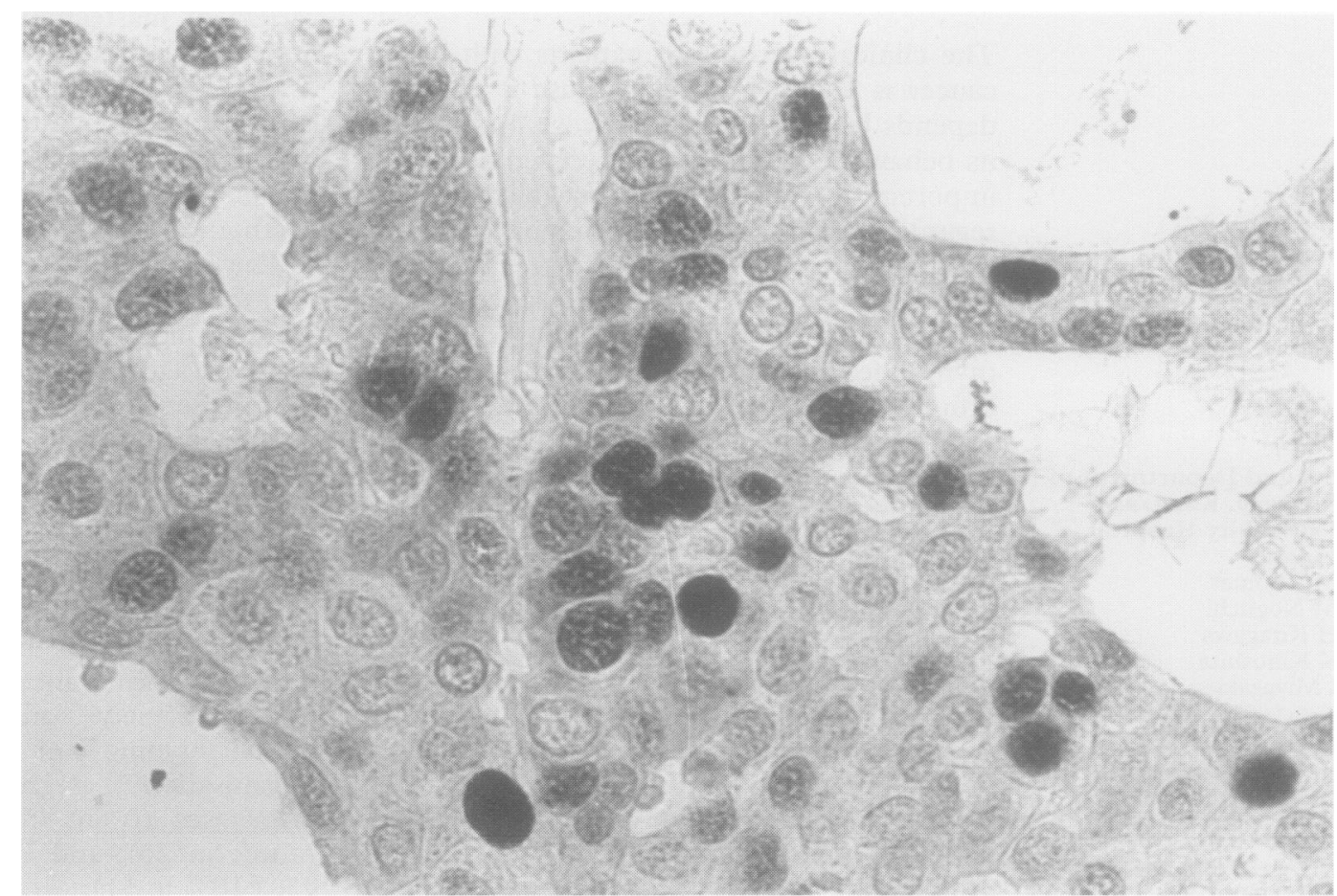


Table 1 Association between PCNA labelling index with clinical and histological variables

\begin{tabular}{|c|c|c|c|c|c|c|c|}
\hline & \multicolumn{3}{|c|}{$P C N A-L I(\%)$} & & \multicolumn{3}{|c|}{$P C N A-L I(\%)$} \\
\hline & $\leqq 18$ & $>18$ & p Value & & $\leqq 18$ & $>18$ & p value \\
\hline $\begin{array}{c}\text { Age (years): } \\
0-35 \\
36-50 \\
\geqq 51\end{array}$ & $\begin{array}{r}7 \\
45 \\
41\end{array}$ & $\begin{array}{r}5 \\
26 \\
20\end{array}$ & NS & $\begin{array}{l}\text { Histological type: } \\
\text { Non-invasive } \\
\text { Invasive duct } \\
\text { Special type of invasive }\end{array}$ & $\begin{array}{r}2 \\
85 \\
6\end{array}$ & $\begin{array}{r}3 \\
45 \\
3\end{array}$ & NS \\
\hline $\begin{array}{l}\text { Menopausal status: } \\
\text { Pre- } \\
\text { Post- }\end{array}$ & $\begin{array}{l}49 \\
44\end{array}$ & $\begin{array}{l}27 \\
24\end{array}$ & NS & $\begin{array}{l}\text { Tumour size: } \\
0-20 \mathrm{~mm} \\
21-50 \mathrm{~mm} \\
\geqq 51 \mathrm{~mm}\end{array}$ & $\begin{array}{l}37 \\
43 \\
13\end{array}$ & $\begin{array}{r}22 \\
26 \\
3\end{array}$ & NS \\
\hline $\begin{array}{l}\text { Clinical stage: } \\
\text { TIS } \\
\text { Stage } 1 \\
\text { Stage } 2 \\
\text { Stage } 3\end{array}$ & $\begin{array}{r}2 \\
21 \\
47 \\
23\end{array}$ & $\begin{array}{r}3 \\
7 \\
29 \\
12\end{array}$ & NS & $\begin{array}{l}\text { AX metastases: } \\
0 \\
1-3 \\
\geqq 4\end{array}$ & $\begin{array}{l}58 \\
17 \\
18\end{array}$ & $\begin{array}{l}27 \\
14 \\
10\end{array}$ & NS \\
\hline
\end{tabular}

LI: Labelling index: AX: Axillary lymph node; NS: Not significant.

of more than $18 \%$. There was no significant correlation between PCNA-LI and all prognostic factors included in this study (table 1 ). On the other hand, the incidence of $\mathrm{AX}$ metastases was evaluated in relation to tumour size and PCNA-LI. The incidence of AX metastases was not related to tumour size and PCNA-LI (table 2). But there was a trend for the incidence of $\mathrm{AX}$ metastases to be higher in the group with a low PCNA-LI.

\section{UNIVARIATE ANALYSIS OF SURVIVAL}

Of the 144 patients, 113 were alive without recurrence in March 1992, five were alive with recurrence, 22 had died of recurrence, and four had died of causes unrelated to breast cancer. Overall and disease free survival were evaluated by univariate analysis (table 3). Significant differences were found between the patient groups with respect to tumour size and AX metastases for overall and disease free survival; clinical stage was significant only as a factor for overall survival (table 3). PCNA-LI failed to identify any group with shorter overall survival and increased risk of earlier recurrence. The 10 year disease free survival after surgery was $75 \%$ in the low PCNA-LI group and $73 \%$ in the high PCNA-LI group; the 10 year overall survival showed a trend towards shorter survival for the low PCNA-LI group (73\%) compared with the high PCNA-LI group $(82 \%)$ (table 4$)$.

Table 2 Incidence of $A X$ metastases related to tumour size and PCNA labelling index

\begin{tabular}{llc}
\hline & \multicolumn{2}{l}{$P C N A$ LI (\%) } \\
\cline { 2 - 3 } Tumour size $(\mathrm{mm})$ & $\leqq 18$ & $>18$ \\
\hline $0-20$ & $10 / 37$ & $8 / 20^{\star}$ \\
$20-50$ & $20 / 44$ & $11 / 26$ \\
$\geqq 51$ & $8 / 13$ & $2 / 3$ \\
\hline
\end{tabular}

LI: Labelling index; *The difference was not significant.

Table 3 Univariate analysis of prognostic variables on overall and disease free survival $(n=144)$

\begin{tabular}{lll}
\hline Variables & $\begin{array}{l}\text { Overall survival } \\
p \text { value }\end{array}$ & $\begin{array}{l}\text { Disease free } \\
\text { survival } p \text { value }\end{array}$ \\
\hline Age & NS & NS \\
Menopausal status & NS & NS \\
Clinical stage & $<0.05$ & NS \\
Histological type & NS & NS \\
Tumour size & $<0.01$ & $<0 \cdot 05$ \\
AX metastases & $<0.001$ & $<0.001$ \\
PCNA-LI & NS & NS \\
\hline
\end{tabular}

LI: Labelling index; AX: Axillary lymph node; NS: not significant.
Table 410 year overall and disease free survival as a function of PCNA labeling index

\begin{tabular}{|c|c|c|c|c|}
\hline PCNA LI (\%) & $\begin{array}{l}\text { Overall } \\
\text { survivals } \\
(\%)\end{array}$ & p Value & $\begin{array}{l}\text { Disease free } \\
\text { survivals } \\
(\%)\end{array}$ & p Value \\
\hline $\begin{array}{l}\leqq 18 \\
>18\end{array}$ & $\left.\begin{array}{l}73 \\
83\end{array}\right\}$ & NS & $\left.\begin{array}{l}75 \\
73\end{array}\right\}$ & NS \\
\hline
\end{tabular}

LI: Labelling index; NS: Not significant.

Table 5 Multivariate analysis of prognostic variables on overall and disease free survival $(n=144)$

\begin{tabular}{lll}
\hline Variables & $\begin{array}{l}\text { Overall survival } \\
p \text { Value }\end{array}$ & $\begin{array}{l}\text { Disease free survival } \\
p \text { Value }\end{array}$ \\
\hline Age & NS & NS \\
Menopausal status & NS & NS \\
Clinical stage & NS & NS \\
Histological type & NS & NS \\
Tumour size & NS & NS \\
AX metastases & $<0 \cdot 001$ & $<0 \cdot 001$ \\
PCNA-LI & NS & NS
\end{tabular}

LI: Labelling index: AX: Axillary lymph node; NS: Not significant.

MULTIVARIATE ANALYSIS OF SURVIVAL

To assess the relative importance and independence of the factors. Cox's multivariate analysis was performed and the results are shown in table 5 . The only independent prognostic factor was AX metastasis.

\section{Discussion}

The presence and extent of AX metastases are the best predictors of prognosis in breast cancer. ${ }^{24} 25$ Despite the confirmed prognostic value of nodal status, ${ }^{26}$ a more basic understanding of the biology of breast cancer is needed to determine which tumour will be more aggressive and necessitate more intensive treatment. Therefore, there has been a constant search for indicators which might elucidate the biological behaviour of breast carcinoma.

Immunohistochemical labelling of tumour cells with monoclonal antibodies against PCNA is a possibility for clinical assessment of proliferation. This has had an important role in the prognosis of various neoplasms. ${ }^{1}$ PCNA is a 36 kilodalton DNA polymerase $\delta$ auxillary protein. ${ }^{27}$ It has been shown that two types of nuclear staining with anti-PCNA can be obtained depending on the fixation: a distinct granular pattern which is S-phase specific; and a more diffuse form which is not S-phase specific. ${ }^{28} 29$ With the monoclonal antibody PC10 used in this study, total PCNA (granular and diffuse) was stained after fixation with formalin. Although PCNA immunoreactivity seems to be limited to the proliferation compartment in normal tissues, knowledge of the association between PCNA expression and proliferation in different kinds of neoplasm is insufficient, especially in breast cancer. ${ }^{12} 151630$ Hall et al ${ }^{16}$ have reported that in some forms of neoplasia, including breast and gastric cancer as well as haemangiopericytomas, the association between PCNA expression and S-phase fraction is absent. On the other hand, Garcia et $a l^{15}$ and Dawson et $a l^{31}$ have recently described that PCNA staining was correlated 
with the $S$ phase fraction. In gastric carcinomas, however, ${ }^{19}$ and in haemangiopericytomas, ${ }^{18}$ PCNA staining still seems to be of prognostic relevance. In all neoplasms studied before, the PCNA-LI seemed to be higher than would have been expected from the $S$-phase determination by flow cytometry. This discrepancy could be explained by the fact that PCNA staining seems to detect not only cells in $S$ phase but also those in late $G_{1}$, $\mathrm{G}_{2}$, and $M$ phases. ${ }^{163233}$ Moreover, the increased expression of PCNA in some tumour types might be a result of autocrine or paracrine stimulation by certain growth factors, ${ }^{16}$ such as platelet derived growth factor, fibroblast growth factor, and epidermal growth factor. ${ }^{34} 35$

The lack of association between PCNA-LI and clinicopathological variables and survival of patients with breast cancer could be attributed to several factors. First, PCNA immunoreactivity is highly sensitive to fixation time, which may change the real PCNA profile of the neoplasms. Second, deregulated expression of PCNA and its prolonged halflife (20 hours) may permit its immunohistochemical detection in cells which have recently left the cell cycle. ${ }^{1016}$ Moreover, PCNA may not only be involved in cell proliferation but also in DNA repair. ${ }^{36}$ Another obvious reason for this lack of correlation is the fact that other factors can be as important as the rate of cell proliferation in contributing to the clinical outcome of patients with breast cancer. It would be very unlikely for a single variable like PCNA-LI to reflect the overall behaviour of such a heterogeneous disease as breast cancer. Finally, immunohistochemistry with PC10 results in very varied labelling, which is apparently not correlated with clinicopathological variables and patient survival in breast cancer.

1 Tubiana M, Courdi A. Cell proliferation kinetics in human solid tumors: relation to probability of metastatic, dissemination and long term survival. Radiother Oncol 1989;15:1-18.

2 Sylvestrini R, Sanfilippo O, Tedesco G. Kinetics of human mammary carcinomas and their correlation with the cancer and host characteristics. Cancer 1974; 34:1252-8.

3 Haag D, Goerttler $K$, Tschahargane P. The proliferative index (PI) of human breast cancer as obtained by flow cytometry. Pathol Res Pract 1984;178:315-22.

4 Gerdes J, Lemke H, Baisch H, Wacker HH, Schwab U, Stein $H$. Cell cycle analysis of a cell proliferation associStein $\mathrm{H}$. Cell cycle analysis of a cell proliferation associated human nuclear antigen defined by the

5 Neubauer A, Huhn D. Monoclonal antibody Ki67 as a proliferation marker. $\mathrm{Br} \mathcal{F}$ Haematol 1987;55:495-8.

6 Miyachi K, Fritzler MJ, Tan EM. Autoantibody to a nuclear antigen in proliferating cells. $\mathcal{F}$ Immunol 1978;121:2228-34.

7 Takasaki Y, Deng J-S, Tan EM. A nuclear antigen associated with cell proliferation and blast transformation. Its distribution in synchronised cells. $\mathcal{f}$ Exp Med 1981;154:1899-909.

8 Mathews MB, Bernstein RM, Franza BR, Garrels JI. Identity of the proliferating cell nuclear antigen and Identity of the proliferating

9 Fairman MP. DNA polymerase 8 PCNA: actions and interactions. F Cell Sci 1990;95:1-4.

10 Celis JE, Celis A. Cell cycle dependent variations in the distribution of the nuclear protein cyclin/proliferating cell nuclear antigen in cultured cells: subdivision of the S-phase. Proc Natl Acad Sci USA 1985;82:3262-6.

11 Morris GF, Mathews MB. Regulation of proliferating cell nuclear antigen during the cell cycle $f$ Biol Chem 1989;264:13856-64.

12 Robbins BA, de la Vega D, Ogata K, Tan EM, Nakamura RM. Immunohistochemical detection of proliferating cell nuclear antigen in solid malignancies. Arch Patho Lab Med 1987;111:841-5.

13 Kurki P, Ogata K, Tan EM. Monoclonal antibodies to a nuclear protein (PCNA/cyclin) associated with DNA replication. Exp Cell Res 1987;168:475-86.

14 Galand P, Degraef C. Cyclin/PCNA immunostaining as an alternative to tritiated thymidine pulse labeling for making S-phase cells in paraffin sections from animal and human tissues. Cell Tissue Kinet 1989;22:383-92.

15 Garcia RL, Coltrera MD, Gown AM. Analysis of proliferative grade using anti-PCNA/Cyclin monoclonal antibodies in fixed, embedded tissues: Comparison with flow cytometric analysis. Am $\mathcal{F}$ Pathol 1989;134:733-9.

16 Hall PA, Levison DA, Woods AL, et al. Proliferating cel nuclear antigen (PCNA) immunolocalization in paraffin sections: an index of cell proliferation with evidence of deregulated expression in some neoplasms. $\mathcal{F}$ Pathol 1990;162:285-94.

17 Kamel OW, LeBrun DP, Davis RE, Berry GJ, Warnke RA. Growth fraction estimation of malignant lymphomas in formalin-fixed paraffin-embedded tissue phomas in formalin-fixed paraffin-embedded tissue using anti-PCI

18 Yu C, Hall PA, Fletcher CD, et al. Immunohistochemical staining with a monoclonal antibody to proliferating cell nuclear antigen may be a good indicator of prognosis in haemangiopericytomas. $\mathcal{f}$ Pathol 1990;161:342A.

19 Jain S, Filipe MI, Hall PA, Waseem N, Lane DP, Levison DA. Prognostic value of proliferating cell nuclear antigen in gastric carcinoma. $\mathcal{F}$ Clin Pathol 1991;44:655-9.

20 Figge C, Reifenberger G, Vogeley KT, Messing M Roosen N, Wechsler W. Immunohistochemical demonstration of proliferating cell nuclear antigen in glioblasstration of proliferating cell nuclear antigen in glioblastomas. pronounced heterogeneity and lack of prognostic

21 Waseem NH, Lane DP. Monoclonal antibody analysis of the proliferating cell nuclear antigen (PCNA) Structural conservation and the detection of a nucleola form. F Cell Sci 1990;90:121-9.

22 Japan Breast Cancer Society. General rules for clinical and pathological record of breast cancer. Tokyo: Kanehara Co, 1988:21-9.

23 The World Health Organization. The world organization histological typing of breast tumors. Am 9 Clin Pathol 1982;78:806-12.

24 Fisher B, Bauer M, Wickerham DL, Redmond CK, Fisher ER. Relation of number of positive axillary nodes to the prognosis of patients with primary breast cancer: to the prognosis of patients with primary brea

25 Carter CL, Allen C, Henson DE. Relation of tumor size, lymph node status, and survival in 24,740 breast cancer cases. Cancer 1989;63:181-7.

26 Haybittle JL, Blamey RW, Elston CW, et al. A prognostic index in primary breast cancer. $B r\left\{\begin{array}{l}\text { Cancer } \\ \text {. }\end{array}\right.$ 1982;45:361-6.

27 Bravo R, Franck R, Blundell PA, MacDonald-Bravo $H$. Cyclin/PCNA is the auxiliary protein of DNA polymerase- $\delta$. Nature $1987 ; 326: 515-7$.

28 Bravo $R$, MacDonald-Bravo $H$. Existence of two populations of cyclin/proliferating cell nuclear antigen during the cell cycle: association with DNA replicon sites. $\mathcal{J}$ the cell cycle: association

29 Van Dierendonck JH, Wysman JH, Keyser R, van der Velde CJH, Cornelisse CJ. Cell-cycle-related staining patterns of anti-proliferating cell nuclear antigen monoclonal antibodies. Comparison with BrdUrd labelling and Ki-67 staining. Am $\mathcal{F}$ Pathol 1991;138:1165-72.

30 Battersby S, Anderson TJ. Correlation of proliferation activity in breast tissue using PCNA/cyclin. Hum Pathol 1990;21:781.

31 Dawson AE, Norton JA, Weinberg DS. Comparative assessment of proliferation and DNA content in breast carcinoma by image analysis and flow cytometry. $A m \mathcal{F}$ Pathol 1990;136:1115-24.

32 Coltrera MD, Gown AM. PCNA/cyclin expression and BrdU uptake define different subpopulations in different cell lines. $\mathcal{f}$ Histochem Cytochem 1991;39:23-30.

33 Woods AL, Hall PA, Shepherd NA, et al. The assessment of proliferating cell nuclear antigen (PCNA) immunostaining in primary gastrointestinal lymphomas and its relationship to histological grade, $S+G_{2}+M$ phase fraction (flow cytometric analysis) and prognosis. Histopathology 1991;19:21-7.

34 Bravo $R$, MacDonald-Bravo $H$. Induction of the nuclear protein cyclin in quiescent mouse $3 \mathrm{~T} 3$ cells stimulated by serum and growth factors. Correlation with DNA synthesis. EMBO $\mathfrak{f} 1984 ; 3: 3177-81$.

35 Jaskulski D, Gatti C, Travali S, Calabretta B, Baserga R. Regulation of proliferating cell nuclear antigen cyclin and thymidine kinase mRNA levels by growth factors. and thymidine kinase mRNA

36 Haneda $\mathrm{H}$, Katabami $M$, Miyamoto $\mathrm{H}$, et al. The relationship of the proliferating cell nuclear antigen protein tonship of the proliferating cell nuclear antigen protein
to CDDP resistance of a murine leukemia cell line P338/CDDP. Oncology 1991;48:234-8. 